\title{
IMPLEMENTASI SPORT SEARCH UNTUK MENGIDENTIFIKASI BAKAT CALON OLAHRAGAWAN BERPRESTASI DI KABUPATEN LOMBK TIMUR
}

\author{
Herman Afrian $^{1}$, Nopi Hariadi ${ }^{2}$ \\ email: armanskm123@yahoo.com ${ }^{1}$,060614.harijadi@gmail.com² \\ Program Studi Pendidikan Jasmani Kesehatan dan Rekreasi, Fakultas Ilmu Pendidikan, \\ Universitas Hamzanwadi ${ }^{1,2}$
}

\begin{abstract}
Community services (PKM) was a form of real work of Penjaskesrek Hamzanwadi University courses in order to closer on communities in Lombok Timur Regency, and forms of devotion which will be funded that is Implementation Of Sport Talent Search To Identify Prospective Athlete Excels. Based on the results of observation of the team associated with Scouting or filtering of talent in Lombok Timur Regency is still using the system and pinpoint the proximity factor sports the Builder parties. The method of implementation of the PKM does is the stage of observation and preparation of infrastructure, it is the exposure to sports data obtained from test results and measurements conducted with 10 kinds of test items from sport search and in interactions right based on the results of the identification of talent and interest of students towards sports activities. The data is processed with computer media with the analysis of using soil existing in sport wear search Ausie Sport Australia. From a number of 80 students as many as 80 students expressed perfectly and can be analyzed, of the four partner schools i.e. SMPN 1 Pringgasela, SMPN 2 Aikmel, MTs. Thohir Yasin and SDN 2 Rakam. The results of the analysis based on rank in SMPN 1 Pringgasela Sport Diving, Trampolining, Gymnastic, Acrobatic, and Weightlifting is very possible to be built. so on SMPN 2 Aikmel Sport Indoor Cricket, Athletics, Cricket, Archery, and the Diving is very possible to be built. In The MTs. Thohir Yasin, sports Athletics, Indoor Cricket, Table Tennis, Archery/Volly Ball, and Kung Fu, it is very possible to be built. In SDN 2 Rakam., Sport Diving/Gymnastic, Indoor Cricket/Table Tennis, Kungfu/Cricket, and extremely Acrobatic, it is possible to be built.
\end{abstract}

Keywords: Implementation Of Sport Search

\begin{abstract}
Abstrak
Pengabdian kepada masyarakat (PKM) ini merupakan bentuk kerja nyata dari program studi penjaskesrek Universitas Hamzanwadi dalam rangka mendekatkan diri pada masyarakat di Kabupaten Lombok Timur, dan bentuk pengabdian yang akan di laksanakan yaitu Implementasi Sport Search Untuk Mengidentifikasi Bakat Calon Olahragawan Berprestasi. Berdasarkan hasil observasi tim terkait dengan pemanduan atau penyaringan bakat di Kabupaten Lombok Timur masih menggunakan sistem tunjuk dan faktor kedekatan pihak pembina olahraga. Metode pelaksanaan PKM yang dilakukan adalah tahap observasi dan persiapan sarana dan prasarana, paparan ini merupakan olah data yang diperoleh dari hasil tes dan pengukuran yang dilakukan dengan 10 macam item tes dari sport search serta diinteraksikan berdasarkan hasil identifikasi bakat dan minat siswa terhadap aktivitas olahraga. Data tersebut diolah dengan media komputer dengan analisis menggunakan soil wear yang ada dalam sport search Ausie Sport Australia. Dari sejumlah 80 siswa sebanyak 80 data siswa dinyatakan sempurna dan bisa dianalisis, dari empat sekolah mitra yaitu SMPN 1 Pringgasela, SMPN 2 Aikmel, MTs. Thohir Yasin dan SDN 2 Rakam. Hasil analisis berdasarkan rangking di SMPN 1 Pringgasela (Kec. PRINGGASELA) cabang olahraga Diving, Trampolining, Gymnastic, Acrobatic, dan Weightlifting sangat dimungkinkan untuk dibina. jadi di
\end{abstract}


SMPN 2 Aikmel (Kec. AIKMEL) cabang olahraga Indoor Cricket, Athletics, Cricket, Archery, dan Diving sangat dimungkinkan untuk dibina. Di MTs. Yhohir Yasin (Kec. MASBAGIK) cabang olahraga Athletics, Indoor Cricket, Table Tennis, Archery / Volly Ball, dan Kung Fu, sangat dimungkinkan untuk dibina. Di SDN 2 Rakam (Kec. SELONG) cabang olahraga Diving / Gymnastic, Indoor Cricket / Table Tennis, Kungfu / Cricket, dan Acrobatic, sangat dimungkinkan untuk dibina.

Kata Kunci: Implementasi Sport Search

\section{A. Penadhuluan}

Salah satu isu Nasional yang sering diperbincangkan dalam berbagai forum dan media adalah masalah tertinggalnya prestasi olahraga nasional. Prestasi olahraga kita boleh dibilang tidak mundur atau merosot, namun peningkatan prestasi olahraga kita mengalami percepatan yang lebih lamban dibandingkan dengan negara-negara lain seperti Cina, Jepang, Korea, dan bahkan Thailand. Tertinggalnya prestasi olahraga nasional dibandingkan negara-negara tersebut mendorong perlu diadakan penataan sistem pembinaan olahraga termasuk sistem pemanduan dan pengembangan atlet berbakat. Sampai saat ini, program pemanduan atlet berbakat belum dikembangkan secara intensif dan spesifik dengan menggunakan pendekatan ilmiah. Kemajuan ilmu pengetahuan dan teknologi (IPTEK) yang sangat pesat dewasa ini membawa dampak dalam berbagai kehidupan termasuk olahraga. Kecanggihan dalam bidang pengukuran dan evaluasi dengan ditemukannya instrumeninstrumen yang dapat digunakan untuk meramal prestasi seseorang, mendorong kita untuk bekerja secara efektif dalam mengidentifikasi dan memilih calon atlet berbakat. Apalagi dalam situasi dan kondisi ekonomi yang terbatas seperti sekarang ini, kita dituntut untuk menggunakan sumber-sumber daya yang lebih efisien dalam pembinaan prestasi olahraga dalam rangka merekrut atlet berprestasi yang memiliki keunggulan kompetitif. Pemanduan calon atlet berbakat harus dimulai dari asumsi dasar bahwa setiap individu diberi kesempatan yang sama untuk berpartisipasi dalam berbagai kegiatan olahraga dan mengembangkan potensi yang dimiliki untuk mencapai prestasi puncaknya. Identiftkasi dan seleksi harus dilakukan dengan cara-cara reliabel dan valid sehingga hasilnya dapat digunakan untuk memprediksi prestasi atlet yang diharapkan. Bibit yang berhasil diidentifikasi dan diseleksi diharapkan memiliki keunggulan komparatif dan kompetitif untuk bersaing ditingkat global (Mutohir, 1995). Substantif akan bermanfaat bagi pengembangan ilmu terapan (teknologi talent scouting) dalam olahraga. Pemecahan masalah yang dilakukan adalah dengan mengimplementasikan teknologi Sport Search sesuai dengan prosedur dari awal hingga akhir. Implementasi ini diterapkan pada siswa-siswi atau calon atlet di Sekolah. Hal ini dilakukan untuk memecahkan masalah Talent Scouting atau pemanduan bakat atlet muda yang berpotensi. Alternalif ini diambil dengan pertimbangan teknologi Sport Search yang telah diadopsi oleh KONI Pusat dan KEMENPORA dalam sistem pembinaan atlet berprestasi.

\section{B. Metode}

1. Metode Pelaksanaan

a) Observasi: pada tahap awal personalia penelitian mencari informasi tempat dan lokasi pada wilayah sasaran

b) Persiapan sarana dan prsarana: tahap persiapan sarana dan prasarana yang mendukung semua kegiatan seperti persiapan tempat dan lokasi pemanduan bakat serta prasarana seperti timbangan berat badan, meteran, papan vertikal jump, bola basket, bola tenis, sound sistem dan kebutuhan tidak terduga.

2. Pelaksanaan Kegiatan

Pelaksanaan kegiatan dari bulan Maret - Agustus 2018 (6 bulan) dan bentuk kegiatan pemanduan bakat menggunakan tes Antropometri yang meliputi: Tinggi badan, Tinggi 
duduk, Berat badan, Rentang lengan, dan tes kondisi fisik yang meliputi: Lempar tangkap bola, Lempar bola basket, Lompat tegak, Lari bolak-balik, Lari cepat 40 meter, Lari multitahap

\section{Hasil dan Pembahasan}

Paparan ini merupakan olah data yang diperoleh dari hasil tes dan pengukuran yang dilakukan dengan 10 macam item tes dari sport search serta diinteraksikan berdasarkan hasil identifikasi bakat dan minat siswa terhadap aktivitas olahraga. Data tersebut diolah dengan media komputer dengan analisis menggunakan soil wear yang ada dalam sport search Ausie Sport Australia. Dari sejumlah 80 siswa sebanyak 80 data siswa dinyatakan sempurna dan bisa dianalisis.

Tabel 1: Paparan Hasil Analisis Berdasarkan Rangking di SMPN 1 Pringgasela

\begin{tabular}{llc}
\hline RANGKING & \multicolumn{1}{c}{$\begin{array}{c}\text { Hasil Data Sport } \\
\text { Search }\end{array}$} & Jumlah \\
\hline I. & Diving & $\mathbf{1 7}$ \\
II. & Trampolining & $\mathbf{1 6}$ \\
III. & Gymnastic & $\mathbf{1 4}$ \\
IV. & Acrobatic & $\mathbf{1 1}$ \\
V. & Weightlifting & $\mathbf{8}$
\end{tabular}

Apabila dilihat dari analisis di atas dari 20 siswa pada Rangking I sebanyak 17 siswa berpotensi di cabang olahraga Diving, pada Rangking II sebanyak 16 siswa berpotensi di cabang olahraga Trampolining, pada Rangking III sebanyak 14 siswa berpotensi di cabang olahraga Gymnastic, pada Rangking IV sebanyak 11 siswa berpotensi di cabang olahraga Acrobatic, ppada Rangking V sebanyak 8 siswa berpotensi di cabang olahraga Weightlifting, jadi di SMPN 1 Pringgasela (Kec. Prenggasela) cabang olahraga Diving, Trampolining, Gymnastic, Acrobatic, dan Weightlifting sangat dimungkinkan untuk dibina.

Tabel 2: SMPN 2 Aikmel (Kec. Aikmel)

\begin{tabular}{clc}
\hline RANGKING & $\begin{array}{c}\text { Hasil Data Sport Search } \\
\text { Cabang olahraga }\end{array}$ & Jumlah \\
\hline I. & Indoor Cricket & $\mathbf{1 5}$ \\
II. & Athletics & $\mathbf{1 1}$ \\
III. & Cricket & $\mathbf{1 0}$ \\
IV. & Archery & $\mathbf{9}$ \\
V. & Diving & $\mathbf{8}$
\end{tabular}

Apabila dilihat dari analisis di atas dari 20 siswa pada Rangking I sebanyak 15 siswa berpotensi di cabang olahraga Indoor Cricket, pada Rangking II sebanyak 11 siswa berpotensi di cabang olahraga Athletics, pada Rangking III sebanyak 10 siswa berpotensi di cabang olahraga Cricket, pada Rangking IV sebanyak 9 siswa berpotensi di cabang olahraga Archery, pada Rangking V sebanyak 8 siswa berpotensi di cabang olahraga Diving, jadi di SMPN 2 Aikmel (Kec. Aikmel) cabang olahraga Indoor Cricket, Athletics, Cricket, Archery, dan Diving sangat dimungkinkan untuk dibina.

Tabel 3: MTs. Thohir Yasin (Kec. Masbagik) 


\begin{tabular}{clc}
\hline RANGKING & $\begin{array}{c}\text { Hasil Data Sport Search } \\
\text { Cabang olahraga }\end{array}$ & Jumlah \\
\hline I. & Athletics & $\mathbf{1 5}$ \\
II. & Indoor Cricket & $\mathbf{1 1}$ \\
III & Table Tennis & $\mathbf{1 0}$ \\
IV. & Archery / Volly Ball & $\mathbf{8}$ \\
V. & Kung Fu & $\mathbf{7}$
\end{tabular}

Apabila dilihat dari analisis di atas dari 20 siswa pada Rangking I sebanyak 15 siswa berpotensi di cabang olahraga Athletics, pada Rangking II sebanyak 11 siswa berpotensi di cabang olahraga Indoor Cricket, pada Rangking III sebanyak 10 siswa berpotensi di cabang olahraga Table Tennis, pada Rangking IV sebanyak 8 siswa berpotensi di cabang olahraga Archery / Volly Ball, pada Rangking V sebanyak 7 siswa berpotensi di cabang olahraga Kung Fu, jadi di MTs. Yhohir Yasin (Kec. Masbagik) cabang olahraga Athletics, Indoor Cricket, Table Tennis, Archery / Volly Ball, dan Kung $\mathrm{Fu}$, sangat dimungkinkan untuk dibina.

Tabel 4: SDN 2 Rakam (Kec. Selong)

\begin{tabular}{ccc}
\hline RANGKING & $\begin{array}{c}\text { Hasil Data Sport Search } \\
\text { Cabang olahraga }\end{array}$ & Jumlah \\
\hline I & Diving / Gymnastic & 16 \\
II & Athletics / Trampolining & 12 \\
III & Indoor Cricket / Table & 8 \\
IV & Tennis & \\
V & Kungfu / Cricket & 5 \\
& Acrobatic & 4
\end{tabular}

Apabila dilihat dari analisis di atas dari 20 siswa pada Rangking I sebanyak 16 siswa berpotensi di cabang olahraga Diving / Gymnastic, pada Rangking II sebanyak 12 siswa berpotensi di cabang olahraga Athletics / Trampolining, pada Rangking III sebanyak 8 siswa berpotensi di cabang olahraga Indoor Cricket / Table Tennis, pada Rangking IV sebanyak 5 siswa berpotensi di cabang olahraga Kungfu / Cricket, pada Rangking V sebanyak 4 siswa berpotensi di cabang olahraga Acrobatic, jadi di SDN 2 Rakam (Kec. Selong) cabang olahraga Diving / Gymnastic, Indoor Cricket / Table Tennis, Kungfu / Cricket, dan Acrobatic, sangat dimungkinkan untuk dibina.

\section{Simpulan}

Penilaian secara keseluruhan dari hasil tes adalah menggunakan sistem komputer dengan program khusus untuk pemanduan bakat atau talent scouting sport search. Yaitu melihat hasil tes setiap siswa dengan nominasi Lima cabang olahraga dari 54 cabang olahraga hasil program komputer yang sesuai dengan antropometri maupun kondisi fisik masing-masing calon Atlit. Siswa yang mengikuti talent scouting ini ialah siswa putra maupun putri yang mengikuti ekstrakulikuler olahraga di Sekolah masing-masing, sebanyak 20 orang setiap sekolah yang terdiri dari 10 putra dan 10 putri dan total siswa yang mengikuti talent scouting ini berjumlah 80 siswa. Adapun saran untuk pengembangan penelitian selanjutnya yaitu: Untuk Peneliti selanjutnya dari segi sarana prasarana, proses dilakukan sefektif mungkin sehingga hasil pemanduan bakat nisa berjalan dengan baik, Untuk obyek atau sasaran sekolah ditambah lebih banyak lagi secara masal, Penelitian ini perlu dikaji ulang lebih detail dalam proses kajian pustaka. 
Creating Productive and Upcoming Sport Education Profesional Hmzanwadi University Vol. 1, No. 1, Juni 2018, Hal. 27-31

e-ISSN 2614-8781

\section{Daftar Pustaka}

Cholik, M. (1996)."Peanduan Bibit Atlet Berbakat dan Beberapa Tes Lapangan”.Prosiding Seminar Nasional Olahraga, Jakarta: Kantor Kemenpora.

Danim, S. (2011)."Perkembangan Peserta Didik". Bandung: Alfabeta

Doewes, M. Furqon H.M (1999). ’Tes Kesegaran Jasmani Dengan Lari Multi Tahap (Untuk Memprediksi Ambang Oksigen Makimal)". Penelitian dan Pengembangan Keolahragaan (PUSLITBANG). Universitas Sebelas Maret: Surakart

Doewes, M. Furqon H. M (2002) "Pemanduan Bakat Olahraga Modifikasi Sport Search".Penelitian dan Pengembangan Keolahragaan (PUSLITBANG). Universitas Sebelas Maret: Surakarta

Kuntadi, D. (1997). "Metode Talent Scouting Sport Search Dan Kemungkinan Aplikasinya Di Indonesia”. KONI Pusat. Jakarta

P3MP. 2016. "Panduan Pelaksanaan Penelitian dan Pengabdian Kepada Masyarakat". Universitas Hamzanwadi; Pancor

Passau, Anwar. "Memilih Atlet Untuk Menghasilkan Prestasi Prima Dalam Olahraga, Dalam Simposium Olahraga - Menuju Prestasi Berolahraga”. (Surabaya: IAIFL, 18 Desember 1986). Sport Search Australian Defence 1994

Sugiyanto. (2013). “Belajar Gerak”. Surakarta: UNS Press.

Suhendro, A. (2004). ”Dasar-Dasar Kepelatihan”. Jakarta: Universitas Terbuka

Sunarto, Agung. H. (2006).” Perkembagan Peserta Didik”. Jakarta: Rineka Cipta 